\title{
Phenomenology, Historical Significance, and the Limits of Representation
}

Perspectives on David Carr's Experience and History

\author{
Jacob Rump
}

\section{Introduction}

The emphasis on experience in western philosophy has waxed and waned. It was close to dying out in the middle of the twentieth century, but is currently in the midst of a resurgence-to such a degree that emphasizing this fact has of late come to be a bit of a cliché. But recent efforts to resurrect a philosophical notion of experience, overplayed or not, are motivated by an important concern and have special importance in the history of philosophy and the history of ideas more generally: they testify to a collective reaction against the inherited presuppositions of the twentieth century's linguistic turn. As David Carr notes in the introduction to Experience and History, the turn to language occurred in both analytic and continental traditions around the same time, though for largely separate reasons. ${ }^{1}$ One area of philosophy in which experience has had a major influence, on both sides of the divide, is in work concerned specifically with history. ${ }^{2}$

For these reasons, we should expect a contemporary work in the philosophy of history that focuses on the concept of experience to be useful not only for those interested in this oft-neglected sub-discipline, but also for the current rethinking of broader philosophical categories and problems - including the continental/analytic divide - after the linguistic turn. On this front, Experience and History does not disappoint.

Like Carr's other books, the work displays depth of analysis, but it also offers a welcome synthetic breadth-a willingness to draw from a wide array of sources in and beyond the phenomenological tradition in order to address broader philosophical problems in a style that nonetheless manages to be light, quick, and a pleasure to read. In a philosophical era too often plagued by hyper-specialization and weighed 
down by jargon, this breadth is at once refreshing and revealing of the progress that can be made by those willing to think about old problems from fresh perspectives.

Carr's various phenomenological perspectives on the historical world are developed through a mix of historical exegesis, original phenomenological analyses, and engagements with the ideas of contemporary authors working on similar themes. The eight chapters of the book hang together as a coherent whole, although as the subtitle indicates, they are not organized into a single overarching argument but instead take on a common theme from several different angles. This review essay will focus on the intersections of a few of these angles in an effort to summarize key ideas, situate them in the literature, and respond to them with an eye to the problematic I find to be most important: the relationship between the historicity of experience, meaning, and representation. Toward the end of the book, Carr notes similarities and differences between his own account of narrative and that of Paul Ricoeur, presenting his own ideas as offering "a slight difference of perspective that is worth underlining, such that my account constitutes, I hope, a useful complement to Ricoeur's" (EH 230). My goal will be to complement Carr's book in a similar manner: I will examine some of his major claims, express a few reservations, and lay out some slight differences in perspective, in the hopes of providing overall a "useful complement" to Carr's work - though I am, in broad outlines, very much in agreement with his central claims.

\section{Minding the Gap}

Theories of history have long been framed in terms of a "gap": as professional historians, but also as laypersons interested in the pasts of our families, cultures, and traditions, we are fascinated as well as frustrated by the irreducible distance between our lives today and that which we wish to access in our past. When we pursue historical research, read a piece of historical writing, or even watch a popular history documentary on television, we are taking part in movements of thought that seek-with differing degrees of complexity and self-reflection-to close that gap. In recent work in the philosophy of history, efforts to close this gap have been constructed in line with two major theoretical preoccupations: representation and memory. Carr's book begins from the premise that while each of these topics is undoubtedly important, their framing in terms of the gap problematic poses an ultimately unhelpful obstacle.

Carr's motivating idea is that a properly framed account of experience can be used to move beyond such an irreducible gap between pre- 
sent and past by insisting on the historical character of experience itself. If the historical is a central component not only of the past but of our very experience of the present (what the phenomenological tradition calls "historicity"), then the problem of minding the gap is resolved, or perhaps better, dissolved, since it will have been shown that there was really no such problem in the first place. This starting point in history's rootedness in experience will have the additional benefit, Carr tells us, of securing a platform for a more robust theory of history that takes account not only of historical knowledge or historical writing (the traditional concerns of philosophers of history in the period of the linguistic turn), but also of the historicity Carr insists is characteristic of human individual and communal life and projects themselves.

The first task, then, is to get clear on what exactly is meant by that philosophically problematic concept, 'experience'. For while the term has certainly rebounded in prominence recently, it is not clear that it has benefitted from any corresponding increase in definitional rigor. To this end, in the first chapter, Carr broadly surveys several senses of the term 'experience' that have been prominent in western philosophy since the time of British empiricism, culminating in the present-day resurgence of the notion after it was downplayed in the middle of the twentieth century amidst the critiques of empiricism and foundationalism (for example, in Sellars and Quine).

Carr identifies four rough notions of experience, two of which are central for his account:

1. The "innocence" of Locke's sensations, Hume's impressions, and Kant's first sense of Erfahrung. To this we can add, without too much distortion, Erlebnisse in Dilthey and Husserl, provided they are decoupled from their foundational role in epistemology.

2. The temporally extended and cumulative sense of experience found in Hume, along with its negative and dialectical version in Hegel, and Dewey. $(\text { EH } 30)^{3}$

Just as the first sense corresponds roughly with the notion of Erlebnis, the second will be recognizable to scholars of nineteenth- and twentieth-century German philosophy as that of Erfahrung. The distinction and relation between them also figures prominently-though without such wide-ranging discussion of its historical pedigree-in Carr's earlier work. ${ }^{4}$ With this distinction in place, Carr claims that "[t]he key to the relevance of experience for the philosophy of history lies in an understanding of how consciousness of the past, and consciousness in and of the present, are related, and this is really the question of how the two forms of experience [senses one and two] are related" (EH 33). 
Carr's brief detour through the modern period also allows him to trace the origins of a broader systematic concern regarding the legacy of epistemology and foundationalism - a concern that lies in the background throughout the book. Modern philosophy sees the mind's relation to the world as presenting yet another "gap" problem: we need to be able to explain the unbridgeable distance between our supposedly subjective, "inner" minds and a supposedly real, objective world "out there." Already stuck within our heads, as it were, we are then confronted with a further gap between ourselves and others, which becomes the "problem of other minds." The desire to overcome these gaps led thinkers from Locke and Kant to the logical empiricists to assign to experience in Carr's first sense of the term the foundational role of defining the scope and limit of our knowledge claims.

This role for experience began to be rejected around the middle of the twentieth century in the anti-foundationalist critiques of figures such as Quine, Sellars, and Kuhn and-across the Atlantic-by the early waves of poststructuralist thought in figures such as Barthes, Derrida, and Foucault. And it is no historical accident that the rise of anti-foundationalism corresponded with the apogee of the twentiethcentury's turn to language, since "it is language that is thought to get in the way of anything like pure experience and to impose on it a conceptual framework" (EH 26). For Carr, however, the (justified) rejection of foundationalism has (unjustifiably) thrown the baby out with the bathwater: if experience does not play a foundationalist role in epistemology, the problematic argument goes, it must play no meaningful role at all, and thus it can be safely ignored as yet another outdated concept, which allows philosophers (continental and analytic alike) to turn their attention to "talk about language, language use, the conceptual schemes that go with it, etc., because that is where the focus of epistemology now lies" (EH 27). Accounts of knowledge, it would seem, may focus on experience or on representational structures such as language, but not on both. Twentieth-century philosophers clearly chose the latter. (I'm not convinced about Carr's assessment of current epistemology as focused so narrowly on such issues-a point I will return to below.)

Carr's rebuff of this rejection of experience is ultimately neither logical nor historical, but phenomenological: that we have experiences and that they matter in our lives is not in the last analysis something to be established via argument; while non-foundational, it is still a certain sort of given (EH 138). ${ }^{5}$ The need to account for the role and structure of experience is not a rational requirement for epistemology but an obvious task for the philosopher that is itself experienced and even felt (EH 32). Phenomenology, beginning with Husserl, has moved beyond the foundationalist quagmire, for Carr, by shifting focus from episte- 
mology to the theory of mind ( $\mathrm{EH} \mathrm{40-1).} \mathrm{While} \mathrm{phenomenology} \mathrm{main-}$ tains the focus on experience characteristic of modern empiricists and rationalists, it does so not out of concern for knowledge in a foundational sense- out of a need to overcome perceived gaps-but because of an insistence on something it takes to be more fundamental: the pervasiveness of mind or consciousness in our projects and our meaningmaking. It is for these reasons that Carr insists on a "decoupling" of our understanding of the first sense of experience he identifies from its association with foundationalism and primarily epistemological concerns.

Carr is certainly right to emphasize the importance of phenomenology's turn to the theory of mind and consciousness. One of the unique strengths of phenomenology in the contemporary philosophical landscape is that it offers the resources of a widely developed systematic philosophy that never fully embraced the linguistic turn, in the sense that it remained interested in the phenomena of lived experience and skeptical of exclusively linguistic or conceptual forms of analysis. As is well known, in his later, transcendental phenomenology Husserl even went so far as to distinguish a separate, non-linguistic conception of meaning. ${ }^{6}$ Indeed, it can even be argued that the later Husserl's account of the pre-given Sinnesfundament of the lifeworld constitutes a version of foundationalism in a different sense, one that remains innocent of the problems that were seen to infect other major versions of it in the twentieth century, because the main purpose of this analysis was not epistemological, in the traditional sense, but transcendental-i.e., it was concerned with the structure of meaning-constitution. ${ }^{7}$ In an environment in which the main focus of theoretical philosophy has shifted from language to mind, and in which there is increased interest in things like non-conceptual content, contemporary philosophers of all stripes would do well to pay greater attention to the rich resources phenomenology has to offer. ${ }^{8}$ Carr does an important service in drawing our attention to the as-yet underexplored historical dimension of this precursor to contemporary work in the philosophy of mind.

But while in his endorsement of anti-foundationalism and his appeal to experience as a given he stands in well-established phenomenological territory, Carr's characterization of phenomenology and of his own position as "moving away from epistemology to something else" (EH 74) needs a more robust defense. It is well known that the phenomenological tradition was conceived by Husserl as a sort of logical and epistemological project, a position that he continued to hold even after the "historical turn" of his later works. ${ }^{9}$ And while it is clear that phenomenology's interests cannot be understood as exclusively epistemological — especially in the excruciatingly narrow and technical sense the term has taken on in some post-Gettier analytic work-it is not clear that a truly phenomenological 
inquiry can be so simply divorced from epistemological concerns in favor of "something else." This is because of the central place that phenomenology (especially the transcendental phenomenological tradition Carr has endorsed in previous work $)^{10}$ accords to the consideration of meaning, even going so far as to consider it a precondition for claims about knowledge or truth. By focusing on meaning in this broader sense, phenomenology forces us to rethink presuppositions concerning the relationship between reality, representation, and knowledge. But precisely because of this rethinking, it seems to me it cannot be said to move away from epistemology; phenomenology instead calls for the constant revision of epistemology. The goal, at least for Husserl (we might argue the case is different for ostensibly more pragmatically oriented thinkers such as Heidegger or Merleau-Ponty), is still theoretical: while the need to account for experience may originally be felt, the phenomenological account that we are thereby inspired to give is surely supposed to be a form of knowledge. And if we have rejected foundationalism, the question of how such knowledge arises on the basis of the constitution of meaning-especially outside representationalist presuppositions-is itself always up for revision as part of the inquiry. Epistemological inquiry is in this sense a necessary component of phenomenology's infinite task and, in the later work, a part of the ongoing analysis of meaning-constitution. In this sense, it is not something we can simply move away from.

Thus, unlike Carr, I am inclined to see epistemology, at least of the phenomenological sort, ${ }^{11}$ as another baby to be rescued alongside experience rather than thrown out with the foundationalist bathwater. Further attention to how we come to know our experience as meaningful may allow us to sketch more fully the deeper historical level of experience that Carr's book succeeds in pointing us toward. Or so I will attempt to show in the remainder of this essay.

\section{Experience, Representation, and Meaning}

In the second half of the twentieth century, the sense of experience as immediate and content-giving (i.e., the first sense of experience in Carr's delineation) has "fallen on hard times" (EH 27) and been threatened to the point of (near) abandonment, as if, after the critiques of foundationalism and the "myth of the given," for all philosophical intents and purposes experience itself no longer existed. Against this trend and in line with the recent resurgence of interest in experience noted above, Carr makes clear that his account of history is interested not only in past things and facts, but also and indeed primarily in the experiential phenomena of events, actions, and persons (EH 3-4). 
When we take off our theoretical hats as philosophers and historians and think about the phenomenon of history as part of our everyday lives, it is these themes, which are associated primarily with human experience, that history really seems to be about. In this turn away from language and toward experience, Carr's work is of a piece with something of a new trend in the philosophy of history. To see what is distinctive about Carr's phenomenological approach to these issues, it will be useful to situate his claims vis-à-vis two of his major interlocutors in this field, Frank Ankersmit and Eelco Runia, each of whose work Carr insists "is not incompatible with and may even be said to complement" his own (EH 67).

Ankersmit's 2005 book introduces the notion of "sublime historical experience"12 explicitly in reaction to the problematic overemphasis on language, which he sees arising largely from the poststructuralist turn to narrative in the philosophy of history ushered in by Hayden White (SHE 36). Ankersmit frames this as a worry about whether the historian can escape the "prisonhouse of language" in order to actually access the past: ${ }^{13}$

Can we rescue the past itself from how we speak about it? More specifically, can the historian enter into a real, authentic, and "experiential" relationship to the past—that is, into a relationship that is not contaminated by historiographical tradition, disciplinary presuppositions, and linguistic structures such as identified by Hayden White in his Metahistory of 1973? . . . [T]he crucial question is whether it is (historical) experience that may enable us to break through the walls of "the prisonhouse of language." (SHE 4)

Ankersmit's answer, like Carr's, is affirmative. As the passage suggests, the notion of representationalism that Carr and Ankersmit object to and that I refer to throughout this essay is one according to which our experience of the world necessarily presupposes a mediating entity that somehow mirrors objective reality in our subjective experiencingan entity commonly assumed, in the twentieth century, to take the form of language or the signifier. ${ }^{14}$

Also like Carr, Ankersmit takes this idea of experience to demand a more robust account of the role of the experiencing subject. In order to rescue accounts of history from a naïve positivism that asks only for the "objective facts" about what happened, we need to move toward a theory that respects the subjective-that is, perspectival-view of the historian on the past she wishes to examine. Ankersmit's appeal to sublime historical experience is supposed to help us do this by simultaneously overcoming a naïve positivism concerning history and the language-oriented, representationalist presuppositions concerning our access to history that-at least in the twentieth century—have often gone with it. 
And yet, despite these major similarities, Ankersmit's notion of sublime historical experience refers to a phenomenon we encounter subsequent to historical writing. For Ankersmit, the appeal to experience functions within the context of a need to make sense of our experience of the historical after the theoretical work attributed to the professional historian:

Only in a thoroughly historicized world, only after the past itself and the historical subject have lost their contours and have been reduced to being mere moments in a Gadamerian effective history, only then will it be possible to break through the thick crusts of effective history and meet history in its quasi-noumenal nakedness. (SHE 277)

Since, on Ankersmit's view, the Gadamerian concept of effective history implies a reduction to the historian's language (SHE 148), independent of language there is in effect no level of historicity to be found:

Historical experience is not the return to a state of primeval innocence, to a state preceding all historical writing - it should be situated, instead, in a realm after or beyond all historical writing. Sublimity enters the scene only after all has been said and done; it has no affinity with beginnings, foundations, first principles, and so on. (SHE 277; emphasis in the original)

In light of our discussion above, it is easy to appreciate the appeal of such a claim: it takes the threat of a return to foundationalism off the table immediately, since for Ankersmit the sublimity of historical experience will only be reached after the explicit representation of our historical situation via effective history and thus after any foundation in "primeval innocence" has been rendered inaccessible.

By contrast, Carr's treatment of experience is seeking something both more everyday and more original: "a connection to the past that is prior to and independent of the historian's interest and is shared by all" (EH 32). Through this connection, he claims, "we may hope to account for why we should be interested (as the historian is interested) in the past in the first place" (ibid.). While he similarly wishes to contrast his position to foundationalism and to primarily epistemological concerns, for Carr, experience is still first. The notion of experience Carr seeks to highlight is not that which arises after the work of historical writing, but that which-when seen in a proper phenomenological light-is there before. This notion of experience is itself a condition for our historical fascination with the world, not only as historians but also as appreciators of family genealogies, readers of history books, watchers of documentaries, and citizens of nation-states with conceptions of shared pasts and convictions about their continued relevance, for better or for worse. Carr's appeal to experience as a way in to the theory of 
history is thus more directly phenomenological: it seeks to understand how in thinking about history our "sometimes grandiose theories arise out of our experience of history - that is, our historicity" (EH 77). The problem that Ankersmit invokes in terms of the "crust" of Gadermerian effective history is then avoided by showing how, in effect, independently of the work of the historian our everyday experience just is already historical and thus already falls under the rubric of effective history.

The contrast is deepened by comparison with Ankersmit's 2012 book, Meaning, Truth, and Reference in Historical Representation. ${ }^{15}$ Here Ankersmit views representation in historical writing as a triadic relation consisting of (1) representation in (roughly) the conventional sense discussed above; (2) the presentation or presented aspect of the thing; and (3) the reality thereby represented (MTR 72). In contrast to traditional linguistic accounts, Ankersmit emphasizes the second notion and carefully distinguishes it from the propositionally oriented model of representation common in contemporary analytic philosophy. Historical representation or meaning cannot be assimilated to linguistic representation à la Frege and the analytic tradition, but rather should be taken as a "primitive term that cannot be defined in terms more basic than itself-and that must therefore remain undefined-whereas other notions, such as Fregean truth, reference, and meaning, can be derived from it" (MTR 139). For Ankersmit, to take meaning as a primitive does not mean to take it as a foundation in the epistemological sense. His point is that meaning-claims have a certain explanatory precedence over truth-claims, which should lead us to reject the Fregean strategy "to somehow define meaning in terms of propositional truth and reference" (MTR 129). Meaning is a first term in the explanation, but not a ground or foundation.

This strategy of taking meaning as primitive conveniently allows Ankersmit to bypass the problem of conventional (linguistic or propositional) representationalism with regard to historical experience. If we insist that meaning - which in this case cannot be a matter of language or propositions - cannot be further defined or analyzed, we also absolve ourselves of the task of explaining how it is that our experience comes to be meaningful or significant for us, or indeed why it is that we are interested in the historical in the first place. As noted above, Carr's account of historical experience does seek to account for this.

If he does not simply wish to take the meaningfulness of historical experience as an undefinable primitive, like Ankersmit, how does Carr deal with the problem of representation? How exactly, on Carr's view, does the historicity of our immediate lived experience by its very nature place us in the presence of that which is meaningful or significant? Even if we accept on phenomenological grounds that historicity does do 
this, it seems as if Carr still owes us some account of how exactly this is to occur outside of representational structures such as language. To put the point differently, if " $t]$ he key to the relevance of experience for the philosophy of history lies in an understanding of how consciousness of the past, and consciousness in and of the present, are related, and this is really the question of how the two forms of experience [senses one and two] are related" (EH 33), how are we to characterize this relation without appeal to a (representational) third term?

Carr's answer to this question comes in the form of his account of the narrative ontological structure revealed in experience itself. Whereas Ankersmit's 2012 account, which is focused primarily on historical writing, is explicitly non-ontological (MTR 72), Carr endorses an explicitly ontological thesis that places experience prior to historical representation, not just retrospectively-in the sense that we must have had a given experience in order to be able to subsequently represent it—, but in the flow of lived experience itself. (I return to Carr's account of narrative in $\$ 5$ of this essay.) Thus, while neither account is foundationalist in the epistemological sense, Ankersmit's approach to historical experience and meaning is "top-down," beginning from the category of historical representation and using its logic to infer characterizations about the status of the past "below" or "before" it, leaving the ultimate category, meaning, undefined. Carr's approach, by contrast, might be called "bottom-up," beginning from the narrative ontology of experience itself and inferring or extrapolating a view of historical reality in accord with it.

Eelco Runia, by contrast, while also noting the problems that arise for representational accounts of historical reality, addresses the issue by moving away from considerations of meaning entirely toward a focus on what he calls "presence." ${ }^{.16}$ Runia explains presence by appeal to the related notion of metonymy, which for him consists in a non-representational "transfer of presence" as opposed to the "transfer of meaning" (P 29). For Runia,

[W]hile a modern monument presents a past event in the here and now, it can hardly be said to represent it. A monument like the Berlin Holocaust Memorial is a repository of what haunts the place of the present, a refuge for what has always (or at least since the event in question took place) been there. It is closer to a relic than to a painted, written, or sculpted pictorial account of what happened. ... [W] [Wereas premodern, metaphorical monuments are primarily engaged in a transfer of meaning, modern metonymical monuments concentrate on a transfer of presence. . . Because the representationalist philosophy of history of the past decades was geared to grasping how metaphor is instrumental in establishing satisfactory representations, it could account for transfer of meaning, but not for (metonymically achieved) transfer of presence. (P 17) 
While Ankersmit's 2012 account deals with the theoretical problem of representationalism by distinguishing between propositional and presentational meaning, and guarantees the purity of the latter from linguistic contamination by assigning it the status of a primitive, Runia takes meaning to be necessarily representational, and simply abandons it in accounting for history in favor of a notion of presence. This brings him closer to a conception of historical experience in Carr's sense-as something that comes before the work of the professional historian and reveals itself in the present.

Indeed, on the question of the role of experience, Runia is much closer to Carr than is Ankersmit. Carr and Runia both presuppose the notion of an "original experience" (EH 67). But Runia goes further, insisting that

Below the surface of the text-in words and phrases we take for granted when we speed along, in expressions we happily forgive the historian, in the concepts and categories the author keeps so masterfully in the air, in the proper and improper names that fill up with color, sense, and meaning-below, I repeat, the surface of the text-the things the metonymies stand for are still present. In absence, but present. The words and phrases that have been woven into the texture of the text are metonymically connected to the places that are left behind-all the way down to the point where names have been substituted for reality. (P 26)

In this insistence on something below the surface of the text, Runia seems to flout longstanding critiques of the "metaphysics of presence." In his turn to the issue of presence, Runia is surely right to insist that there is a level of significance evident in experience as a "stowaway"below that of representation, but also below the level of our consciously chosen life-projects, activities, and intentions. But the stark contrast he draws between presence and meaning seems phenomenologically inaccurate in that it has the effect of abandoning the analysis of meaning altogether. Are such presences not meaningful? And is it not this meaningfulness or significance that—as Carr suggests—first draws us to history?

If my claim above about the deep importance of a broad and not exclusively linguistic conception of meaning for phenomenology is correct, it should give us reason to question Runia's dismissal of meaning. What Runia wants to call "presence" or "metonymy" might be better described as non-representational meaning (taking representation in the sense noted above). A suitably specified version of such a notion would allow for the move beyond representationalist preconceptions concerning history (a goal shared by Runia, Ankermsit, and Carr), while still respecting its rootedness in the historical quality of our 
everyday experience, and while still overcoming the representational gap that is the common target of these accounts. Such a conception seems to me to be implied (though admittedly never directly stated) in Carr's simultaneous desire to remain wary of "recent and important philosophical reflection on the "metaphysics of presence" while still insisting on the "reference of representation and memory back to experience" (EH 67).

Like Ankersmit's, Carr's treatment of the gap problematic recognizes the need to move beyond the representational structures of language. And like Runia, he recognizes that such an account needs ultimately to be rooted in a conception of experience prior to historical writing. Contra Runia however, Carr's analysis, in its focus on the everyday significance of the historical, suggests that what is missing is still an account of meaning in historical experience; the difference is that this account is one in which the ties between it and things like representation and language have been problematized and rethought. But, as I argue below, his account could go further in describing more precisely the way in which this historical experience functions in concreto and thereby how exactly meaning or significance comes into play at this deeper level.

\section{Memory, Temporality, and Community}

Like representation, memory has become a central and much-contested notion in recent work in the philosophy of history. If the historian's task is to establish knowledge about the meaning of past events, actions, and persons, the capacity for memory is centrally involved. And memory too implies a gap: in order to remember, we must to some degree have forgotten —or at least ceased to actively notice-something of significance.

This preoccupation was central, for example, in the French historian Pierre Nora's massive project in the 1990s of cataloguing French "places of memory." ${ }^{17}$ Nora explicitly seeks to overcome what he sees as a lack of collective memory in the modern French consciousness. In the face of this loss of "real memories," Nora claims, we have developed lieux de mémoire, sites that act in material, symbolic, and functional ways to replace our "depleted fund of collective memory." 18 Here too then there is a gap-in this case, one that arises due to a failure of collective memory and one that is understood to be bridged in some way by representation. Nora thus uses representation in roughly the sense Runia rejects in favor of presence and metonymy. Representation and memory are not only the major preoccupations of recent theories of history; they are also often deeply intertwined. 
Carr's strategy for overcoming this difficulty, as with the case of representation, is to base his account on something "closer" to our everyday lives than the traditional notion of memory. If he can show that our everyday lived experience is itself historical, and not only through the mediation of explicitly represented memories, the perceived need to overcome a gap by positing representational bridge notions such as Nora's lieux de mémoire is not so much met as it is rejected as a pseudo-problem. With a suitable focus on the structure of our everyday experience and its already-historical attributes, we will see that the problem of the gap in the philosophy of history need not vex us in the first place.

In this vein, Carr seeks to phenomenologically refine our conception of memory's relation to experience. Here, as in earlier works, he appeals largely to Husserl's theory of time-consciousness. The past functions in experience not only through the recording of now-past perceptions, but also in a broader and non-thematic way: the explicit function of memory as recollection (e.g., when I representationally remember what I had for breakfast yesterday) is contrasted with the phenomenon of retention, which provides the implicit (and non-representational) background or horizon from which my present experience arises on the basis of my history, habits, etc. From the phenomenological standpoint, retention is a condition of the possibility of recollection, not the other way around (EH 72); it is "joined to the present, so intimately that it plays a role in constituting the very sense of the present" (EH 37).

Paralleling the recollection-retention distinction, protention-our implicit anticipation of future experience-is contrasted with explicit expectation about the future (e.g., our hopes, dreams, and worries). Here again, the point is not that we have no representations of possible future events, but that-from the standpoint of lived experience-such explicit representations presuppose something more original and nonrepresentational. Past experiences thus shape our present experience both explicitly, as expectations formed in concert with the representational contents of memory, and implicitly, due to the protentional structure of consciousness below the representational level (EH 47). As was the case with representation, a careful study of memory in light of phenomenological insights has led us back to the historicity of everyday human experience through what Ankersmit called a "rescuing" of subjective experience (SHE 4), but in a way that does not condemn our historical understanding to the "prisonhouse of language."

In Carr's case, however, this return is not simply subjective but first and foremost intersubjective. Here Carr again follows the insights of the phenomenological tradition: what is retained in retention, like what is recollected, is not entirely - though it is partly-a result of free and 
autonomous individual choice. The "sedimentation" of meaning, as Husserl's late work emphasized, results from the social structures, traditions, etc., that shape my experience and my everyday life, as well as from structures of my individual subjectivity. Thus, alongside the extension of an account of memory and expectation to include the temporal structure of retention-protention, Carr also argues for a stronger conception of actions and motivations at the level of the collective or the group. A phenomenologically accurate description of historical experience does not make sense as an exclusively individualistic one. The buttressing of an account of memory as explicit representation of past and forgotten events with an account of the more orginary phenomenon of retention is coupled with a shift from the individual subject to the communal or "we-subject," a continuation and enhancement of the phenomenological emphasis on the first person to include the first person plural (EH 50-1). This allows Carr to preserve and extend the centrality accorded by phenomenology to the intentionality of experience. The world shows up as "a complex of meaningful things and events" $(\mathrm{EH}$ 43) not only individually but also-indeed primarily—collectively or socially: I do not assume that the world of my experience is meaningful only for me. It is in this light that Carr describes his project as "a phenomenology of the interplay of points of view" (EH 197).

The appeal to the we-subject in turn sets the stage for what is one of the most important, original, and provocative claims in the book. Carr states unequivocally: "I want to contend that it is in the experience of membership in communities that time is genuinely historical for us. As a member of a community I become part of a We-subject with an experience of time that extends back before my birth and can continue even after my death" (EH 52). Since the temporal-intentional structure of the we-subject will mirror that of the individual subject, Carr contends, this notion allows us to move beyond memory - even collective memoryand grants us a form of access to history in the genuine sense, the sense in which we speak of the history of societies, civilizations, and peoples.

For Carr, it is through this collective temporal-intentional structure that we are confronted with the "peculiar intersubjectivity" (EH 60) of historical events such as September 11, 2001, the 1989 fall of the Berlin Wall, and the 2008 United States presidential election. In such cases, "we didn't need subsequent occurrences to know that these events were historically significant. We knew it at the time and in and through the experience itself" (EH 59). And it is of the utmost importance that each of us understands this significance as recognized by us and not simply by me: what is ultimately characteristic of the experience of historical events, for Carr, is their significance for us collectively in the present, which he insists is "not merely symbolic" but also "felt" (EH 61). 
But here, it seems to me, the question again arises of how exactly the historically meaningful comes into play outside the structures of representation. If in the case of such historical events we are able to access an historical significance that is at least in some cases not only representational but also felt, then it seems as if we need to extend the phenomenological conception of the individual experience of the "living present" as felt and embodied to include a community form of feeling and embodiment. Carr's descriptive account of the experience of history should be extended not only to the we-subject but also to a communal notion of embodiment.

Admittedly, this is no easy task. While it is easy to envision an account of an individual subject's intentionality extending beyond or below the level of representation by appeal to arguably more originary embodied, non-representational structures such as affect or kinesthesis, it is much more difficult to conceive of this analysis expanded to the level of the we-subject. For our appeals to shared meanings or intentionalities always seem to fall back on representational or semiotic notions ultimately rooted in individual speakers or thinkers, even if they often speak "with one voice." Indeed, Carr's analysis of we-intentionality proceeds largely via evidence from linguistic usage: when we say "we" (EH 50, 70) or "use the term "we" (EH 52). Similarly, he claims, "it is primarily as members of communities of various sorts that we experience the reality of the past in our present lives. It is here that such terms as 'tradition,' 'inheritance,' legacy,' come into play" (EH 54; emphasis added). If Carr has succeeded in extending his account of the historicity of experience to the we-subject, it is not clear that he has adequately explained how we can know the significance of historical events in a present, direct and unmediated way, independent of the gaps of representation or memory. Since their capacity to function nonrepresentationally was a major reason for Carr's analysis of retention and protention (as opposed to recollection and expectation), which constitute the "level of temporality" at which he locates such historical events, it seems the reader is owed a bit more here: linguistic usage may provide good evidence for the existence of the we-subject, but it tells us very little about the non-representational structure of we-intentionality.

The need for an account of embodied intentionality at the intersubjective level has been emphasized in recent phenomenological work inspired by Husserl (especially his genetic phenomenology), on themes such as personhood and social ontology. Timo Miettinen has recently argued, for example, that "others are indeed there already at the elementary level of world-experience ... not as objects to be constituted or bodies to identify with but as the manifold of possible perspectives." ${ }^{19}$ This recalls Carr's own characterization of his book as "a phenomenol- 
ogy of the interplay of points of view," but at the level of what Husserl called "passive synthesis," which occurs below the level of conscious, representational awareness and is characterized primarily in terms of functions of the lived body.

Is Carr's we-subject also embodied in a more substantial sense than the mere "collective" embodiment of its individual members? It seems that Carr should want to answer this challenge in the affirmative since part of his point is that experience is a more originary structure than representation and that the latter is not sufficient to fully account for the former, at least in the case of history. Whereas Carr refers to the "reference of representation and memory back to experience" (EH 67; emphasis added), it might serve him better to speak of the "rootedness" or "embeddedness" of these phenomena in a collective lived experience that is, at its most originary level, already meaningful because it is embodied.

\section{Narrative and the Transcendental Structures of Historical Experience}

Closely related to the "genetic" considerations mentioned above, one of the most important insights of Husserl's later historical turn-a notion taken up with various revisions and extensions by phenomenologists after him-, was that we need a deeper transcendental account of meaningful experience below representation and structures made explicit to consciousness. Indeed, this is one way in which Husserl's work avoids the problematic presuppositions of the linguistic turn discussed above: for him, meaning is always first and foremost a category of lived experience and only derivatively one of language or the conceptual. In the previous section I suggested some ways in which Carr's treatment of historicity - while it certainly takes account of this insightmight make more of it by appealing to the lived body. Here I want to focus on another area in which Carr's book already moves in the direction of Husserl's insights concerning meaning: his account of the narrative structure of human experience. Further attention to this aspect of Carr's account will also allow me to return to some of the issues concerning representation and language raised in $\S 3$ of this essay.

For Carr, narrative structure pervades even our lived experience of time itself, since "experience of time is a function of the events that I live through, the events, that is, that are meaningful or significant for me. It is these events, not abstract points on a scale, that are ever receding into an indefinite background and make up the horizon of my past" (EH 179). Carr goes on to show how such horizons are organized via the protention-retention structure at a primary level, and at a sec- 
ondary level by memory and explicit expectation. Together, "these primary and secondary horizons of past and future form the complex background against which the 'now' stands out and from which it derives its significance" (ibid.). Given Carr's objections against representational and memory-based accounts of history, recollection and expectation cannot themselves constitute our primary horizons because they presuppose the very gap Carr's appeal to the temporal primacy of the protention-retention structure is intended to overcome.

But to say that the protention-retention structure provides us access to historical significance is not yet to say how it does so. If, at this most basic level of horizons, representation has not yet entered the picture, how exactly does the "now" of our experience "derive its significance"? How does meaning enter the picture here at all?

Carr speaks to this issue in Experience and History through a renewed focus on narrative- extending and correcting central claims from Time, Narrative, and History. ${ }^{20}$ This earlier account, Carr tells us, took narrative as the mediating term between historical writing and historical reality ( $\mathrm{EH} \mathrm{69).} \mathrm{This} \mathrm{risked} \mathrm{overshadowing} \mathrm{Carr's} \mathrm{main} \mathrm{point} \mathrm{in} \mathrm{the}$ earlier work - that historical writing and the sense-making undertaken by the historical agent share a common formal structure-by "reifying" the metaphor in a way that suggested that "a given historical narrative simply reproduces a 'real' narrative already embedded in reality" (ibid.). Carr's earlier conception, we might say, remained too closely tied to the problematic of representation. To correct for this, Carr now insists that experience itself be taken as the mediating term between historical writing and historical reality. Experience can be understood on its own terms, outside the comparison to narrative, even if it "turns out in its temporal structure to have narrative features" (EH 70). This "ontologization of narrative," or the "narrative mode of existence," corresponds to a certain level of experienced reality—presumably, though this is not always entirely clear, that which corresponds to the primary level of horizons (EH 225).

Carr's "ontologization" of narrative-making it part of the structure of experience itself-is supposed to help show how the historical character of experience is a necessary part of the "making sense" of the world in general, and that this is simply what we, as human beings and meaning-makers, do. Self-constitution is a form of self-narrationan idea traceable to Dilthey's appeals to autobiography and life-histories (EH 228-9). This is the important insight of the later nineteenth- and twentieth-century hermeneutic tradition: the focus on a process of selfinterpretation and "the discovery or revelation of meaning" (EH 227). To put the insight in the terms of the early Heidegger, the act of (self) understanding is itself constitutive of the being of Dasein; my meaning 
does not precede me. This ontological nature of narrative is revealed in grasping the meaning of an action (as opposed to understanding as grasping the meaning of an expression) and locating it in the "plot" of our daily lives (EH 228). Carr thus embraces the Heideggerian and Gadamerian claim to a transformation of hermeneutics from an epistemological to an ontological project, recognizing a fundamental structure of human being-in-the-world and thereby explaining why we are interested in history in the first place (EH 77). Human actions, intentions, etc., are always already "real in a sense that can never be touched by metaphysical speculations-that is, they matter" (EH 208). For Carr, this explains how the "now" of our experience "derives its significance" independent of representation: since "[a]ction does not exist independently of its meaning" (EH 228), in effect it always already had it. ${ }^{21}$

To illustrate this idea, toward the end of the book, Carr presents an extended analysis of a passage from Simon Schama describing Sir Walter Ralegh ${ }^{22}$ planning an expedition. Carr writes:

Here Ralegh is presented as a human being in the human world. His physical surroundings are not just impinging on him causally; they have significance for him, a significance which is derived from their relation to a long-term project in which he is engaged. In this sense they are embedded in a story which Ralegh is projecting before himself and which he will proceed to act out. This is the primary narrative which shapes the human time of Ralegh's own past, present, and future. It is this first-order narrative that Schama's second-order narrative is about. (EH 210-1)

In contrast to the conventional "secondary narrative" of the historian, "primary" (or proto-) narrative corresponds to the level that Carr wishes to "ontologize" in his account.

But in his emphasis on narrative as an ontological category, it seems to me that Carr too severely downplays what might be considered an equally fundamental pre-condition of historical experience. Without going so far as to endorse an ontology of "the event" 23 or an account of "spontaneous sense formation," ${ }_{24}^{4}$ we might still think that there is much more going on here "below the surface" of narrative that is missing from Carr's account, but which is still open to phenomenological description.

Carr's notion of the primary level of narrative is closely tied to a conception of agency, as we see in his focus in the passage above on Ralegh's intentions for his "project" and a story which he "projects before himself" (EH 210-1). But there is surely something else at play: without denying the ways in which the significance of Ralegh's surroundings "is derived from their relation to a long-term project in which he is engaged" (EH 210), can we not also admit other factors that help to determine this significance-factors not so easily attributed to the 
agent or his projects? What about the norms of masculinity and social status that helped to shape the very projects Ralegh undertook and even his choice of career? What about the material affordances made possible by the technological advances of Ralegh's day, e.g., the advent of ships capable of long voyages such as that envisioned for the Guiana expedition? It seems that there are other non-agential elements that are determinant even of the rules or conditions of possibility for such "first-order" agential sense-making-Carr's "primary narrative." And this set of structures or determinants seem to be, in Husserl's terms, largely passive, not something actively constructed by the agent, even in terms of possibilities, but rather in some more primordial sense, determinant of what possibilities there might be.

Taken by itself, Carr's account of historicity in terms of narrative seems to me to imply an overly active understanding of the subject. While it does manage to steer a middle course between determinism and relativism, as Carr intends (EH 196), it does not do justice to the background conditions that so extensively determine the narratives of our lives. Capturing the full picture requires, in my view, a complementary perspective less directly oriented to consciousness and agency.

Carr himself seems to have a similar worry and even makes clear that his book is not intended to be merely an "agent's intent" account: "[t]elling the story of an action," he explains, "involves more than just finding the motive, thought, or intention behind the action: It ties the action to its background circumstances, its antecedent events, and its subsequent results" (EH 223). And yet, his subsequent account of these "circumstances and events" consists primarily of an extension of the agential account from the level of the 'I' to that of the 'we':

[I]n history, the "constitution" deriving from the narrative activity of the historian is preceded by the narrative self-constitution of social entities. One may be tempted by a certain idealism, since some social entities seem to have been created or invented by historical retrospection. . . . But even here, it is a question of reinterpreting activities and events that had their original existence as a first-order narration at the level of the social group. (EH 231; emphasis added)

This is of a piece with Carr's second proposed revision to his earlier account of narrative. Alongside the ontologized conception of narrative, he now argues that we need a more explicitly phenomenological, de-ontologized understanding of the we-subject involved, thus distancing his view from an understanding of the we-subject as an independent objective reality — as it might be understood, for example, in Hegel's philosophy of history-in favor of a view of we-subjects as "fragile entities that form themselves in certain circumstances and just as easily dissolve 
when circumstances change" (EH 69). Carr thus extends the individual conception of sense-making by means of his earlier emphasis on communities and we-intentionality, resulting in a sort of "softening" of the notion of agency by emphasizing its embeddedness in group narratives and motivations: "It is not just the intended consequences of an action, its plausible 'outcomes,' that make it comprehensible; it is the whole sweep of its future horizon, from the agent's point of view, the long-term destiny of the individual or the group, which forms the ultimate frame for the action" (EH 193; emphasis added).

But does this move from the individual to the social level really go far enough to allow us to make sense of the ways in which circumstances affect the historical structure of experience? If the we-subject is itself formed and disbanded in part according to circumstances beyond its purview, then surely it can no more fully determine those circumstances than can the I-intentionalities that make it up. Thus, in my view, while it is a positive development, it does not go far enough to extend the project of a "phenomenology of interplay of points of view" to the social level (EH 197). For the interplay that is relevant here is also an interplay with circumstances and things that have a significance that is not entirely of my-or even our-making. The move from the individual to the social level in terms of narrative structure extends this problem to a new level, but it does not manage to fully solve it. While the analysis of narrative as an ontological structure is certainly revelatory, I'm not willing to go as far as Carr does in claiming that it is "narratives all the way down" (EH 223).

This review essay is not the place to elaborate my own position concerning what other, non-agential structures are involved in the structuring of historical significance. But let me gesture very briefly in two directions, each of which is hinted at in Carr's account ${ }^{25}$ but in my view underemphasized by contrast to the focus on narrative.

First, consider the issue of normativity. At one point, Carr suggests that narrative constitutes something like what the later Wittgenstein calls a Lebensform (EH 229). This point of comparison is instructive. While the exact interpretation is contentious, what Wittgenstein seems to intend with this notion is a set of basic normative practices that serve to undergird our common language-games. ${ }^{26}$ Carr characterizes Husserl's account of theoretical truths as concerned with questions and problems that "do not come out of the blue, but out of a tradition of ongoing inquiry," whose "prior solutions furnish the context and background" (EH 49). With Wittgenstein, I would argue that this insight applies not only to scientific enterprises but even to the normative practices that characterize our daily life. And conditions here are not exclusively those determined by the narrative ontology of the (individual or 
collective) agent: the background context here will also include things like the normative consistency of experience itself. In Wittgenstein's words,

[I]f things were quite different from what they actually are-if there were, for instance, no characteristic expression of pain, of fear, of joy; if rule became exception, and exception rule; or if both became phenomena of roughly equal frequency-our normal language-games would thereby lose their point. The procedure of putting a lump of cheese on a balance and fixing the price by the turn of the scale would lose its point if it frequently happened that such lumps suddenly grew or shrank with no obvious cause. (PI 142)

Though outside the purview of active agency, such practices as measurement (or Wittgenstein's more famous example of the speaking of a language [PI 23]) help to normatively determine the possibilities for our projects and narratives in that they provide certain conditions for success or failure ultimately beyond our control. ${ }^{27}$ Even if the exact role of representation (language-games) is different in Wittgenstein's case, this insight suggests the need for further consideration of the norms that must be in place as a precondition for common historical experience. ${ }^{28}$

My second, related suggestion comes from the later Sartre. In his discussion of the "peculiar intersubjectivity" manifest in the experience of historical events, Carr makes reference to Sartre's conception, in the Critique of Dialectical Reason, ${ }^{29}$ of the "group-in-fusion" (EH 60). In Sartre's account of historicity and social ontology in this work, this notion is intimately bound up with another notion-that which he calls the "practico-inert"-which is the result of group intentionality and activity, but which is manifested in material conditions that, often because of their very materiality, are now alienated from and resist the group. ${ }^{30}$ This seems to me especially important if we consider the impact of technology on questions of history. Carr mentions television as our main form of access to historical events such as September 11. But even if we are able through this medium to experience historical events in the present, as they are happening, doesn't technology change our access to these events in some way? What about social media, or the 24-hour news cycle according to which everything seems to be treated as a world historical event, at least until the public loses interest? In order to account for such potential changes in our lived temporality, we need to pay closer attention to the ways in which the products of weintentionality have themselves come to determine the structure of our lived experience. If "the globalization of space and time in the contemporary world is not so much the triumph of the objective as it is the rise of a new culture of space and time, still living uneasily with the old" 
(EH 183), we would do well to focus specifically on the structures through which this new culture is manifested. And it is not clear to me that such structures will be captured by an account of historical experience that hews too closely to the narrative dimension.

\section{Conclusion}

It should be noted before concluding that my examination of Carr's major claims has largely neglected his account of the "classical philosophy of history" (chapter 4), his own "phenomenological re-reading" of it (chapter 5), and perhaps most significantly, his exegesis of the origination of many of these ideas in the phenomenological tradition (chapter 6). As we should expect from a scholar who has engaged with these ideas and authors for many years, these chapters are exemplary and do much to support his main claims and to add historical and exegetical justification to the ideas I have engaged exclusively on an argumentative level here. But I don't think they obviate the critical complements I have suggested.

A final word on this will allow me to return to the broader considerations from which this essay began. My suggested complements to Carr's account stem from a difference in perspective concerning the need to move away from epistemology to considerations of mind and, in the case of narrative, to ontology. Carr resists "conventional epistemology" (EH 230) because he sees in it problematic remainders of a thoroughgoing representationalism and of foundationalism, both of which-in their traditional forms at least-he rightly seeks to reject. I have tried to suggest, by contrast, that if meaning is at least in some sense to be located directly in our experience with the world and not only in our talk about it, then the project of explaining and not just asserting the direct connection between experience and meaning demands a corresponding clarification of the epistemic structure of historical significance. "Founding" will mean something very different when taken in this light. Indeed, Ricoeur himself, not in his work on narrative but in his own Husserl exegesis, reminds us of just this point: for the later Husserl, "founding no longer signifies elevating to intellectuality, but on the contrary it signifies building up on the basis of the primordial, of the pre-given." ${ }^{31}$

If we reject the exclusivity of linguistic and conceptual models for the explanation of experience, and ipso facto representational meaning, epistemological questions no longer need to be suspended or avoided. Carr is right that the historical significance of experience is ultimately something "felt." But if we are to write books and articles about it, we should also attempt to describe as completely as possible how we come 
to know it. From this perspective, we are perhaps better off attempting to answer anew, and not to reject, the epistemological questions that arise in the landscape of twenty-first-century philosophy. Phenomenology still offers powerful tools for such epistemological clarification and is uniquely positioned for this task because its descriptive method is not undertaken in fidelity to foundationalism or representationalism, but instead to the everyday experiencing of significance; in this respect, phenomenology takes its cue not only from the conscious subject but also from other everyday manifestations of "the things themselves."

While his critical engagements with problems of representation are far from the only merits of Carr's considerations of experience and history, I have focused on them here because of the way they help to break new ground. In a twenty-first-century characterized by increasing doubts from all manner of continental and analytic philosophers concerning the representational presuppositions of the twentieth century, Experience and History illustrates the centrality of both phenomena represented in its title for reaching more nuanced perspectives on our shared, lived world.

\section{NOTES}

1. See David Carr, Experience and History: Phenomenological Perspectives on the Historical World (Oxford: Oxford University Press, 2014), p. 2; henceforth $\mathrm{EH}$, followed by page number.

2. Though today we may tend to think of history as a concern primarily of those in the continental tradition, the sub-discipline of philosophy of history maintained a place as a respected subdiscipline in the AngloAmerican philosophical world until at least the 1960s. The dying out of the philosophy of history as a theme of concern among analytic philosophers in the last third of the twentieth century may in fact be due to the reaction against conceptual and linguistic analysis that ushered in the displacement of the philosophy of language by the philosophy of mind as the core of the (post-) analytic research program. See Guiseppina D'oro, "The Ontological Backlash: Why did Mainstream Analytic Philosophy Lose Interest in the Philosophy of History?," Philosophia 36:4 (2008), pp. 403-15.

3. Carr also identifies a second sense of Erfahrung in Kant corresponding to the empirical knowledge of objects (EH 30).

4. See, for example, David Carr, The Paradox of Subjectivity: The Self in the Transcendental Tradition (Oxford: Oxford University Press, 1999), pp. $70 \mathrm{ff}$. 
5. Carr's formulation here and at some other points in the book raises the interesting and important question of whether phenomenology is guilty of Sellars' "myth of the given." For recent treatments of this issue, see chap. 19 of Claude Romano, At the Heart of Reason, trans. Claude Romano and Michael B. Smith (Evanston: Northwestern University Press, 2015), pp. 403-31; and the appendix to Carl Sachs, Intentionality and the Myths of the Given: Between Pragmatism and Phenomenology (London: Pickering and Chatto, 2014), pp. 157-68, where Sachs reaches the somewhat surprising verdict that, while Husserl is guilty of the myth of the given, Merleau-Ponty is not.

6. See Edmund Husserl, Ideas I (General Introduction to a Pure Phenomenology), trans. Fred Kersten, bk. 1 of Ideas Pertaining to a Pure Phenomenology and to a Phenomenological Philosophy, vols. 1-3 of Collected Works, ed. Ullrich Melle (New York: Springer, 1982), vol. 2, pp. 294-7; Allgemeine Einführungin die reine Phänomenologie, ed. Walter Biemal, bk. 1 of Ideen zu einer reinen Phänomenologie und phänomenologischen Philosophie, vols. 3-5 of Husserliana, ed. Ullrich Melle (The Hague: Martinus Nijhoff, 1950), vol. 3, pp. 256-9.

7. See, for example, Edmund Husserl, The Crisis of the European Sciences and Transcendental Phenomenology: An Introduction to Phenomenological Philosophy, trans. David Carr (Evanston: Northwestern University Press, 1970), pp. 48-53; Die Krisis der europäischen Wissenschaften und die transzendentale Phänomenologie, ed. Walter Biemel, vol. 6 of Husserliana, ed. Ullrich Melle (The Hague: Martinus Nijhoff, 1976), pp. 49-54.

8. It is telling, in this respect, that recent work in the (analytic) philosophy of mind has witnessed a great resurgence of interest in the work of Brentano, largely due to his account of intentionality, but comparatively less in the classical phenomenological figures such as Husserl who further developed that account. This is itself no doubt a result of the differences in approach and training that persist as the legacy of the continental/analytic divide.

9. This is a topic on which, it must be noted, Carr is well qualified to comment, as both the English-language translator of the Crisis and the author of a monograph on Husserl's views on the topic (Phenomenology and the Problem of History: A Study of Husserl's Transcendental Philosophy [Evanston: Northwestern University Press, 1974]).

10. See, in particular, Carr, The Paradox of Subjectivity.

11. For a systematic presentation of "phenomenological epistemology," see Henry Pietersma, Phenomenological Epistemology (Oxford: Oxford University Press, 2000).

12. Frank Ankersmit, Sublime Historical Experience (Stanford: Stanford University Press, 2005); henceforth SHE, followed by page number.

13. [Ed.-This phrase is indirectly attributed to Friedrich Nietzsche by Ankersmit (SHE 75). However, this attribution ultimately appears to be based on a loose translation of a remark by Nietzsche in The Will to Power, trans. Walter Kaufmann and R.J. Hollingdale, ed. Walter 
Kaufmann (New York: Vintage Books, 1967), p. 283. For a discussion of the genealogy of this translation, see Ernst Behler, "Translating Nietzsche in the United States: Critical Observations on The Complete Works of Friedrich Nietzsche," in Translating Literatures, Translating Cultures: New Vistas and Approaches in Literary Studies, ed. Kurt Mueller-Vollmer and Michael Irmscher (Berlin: Erich Schmidt Verlag, 1998), pp. 142-3.]

14. When representation is understood in a more limited sense, e.g., along the lines discussed later in this section with regard to Ankersmit's notion of the representation (or presentation) of aspects, calls for "non-representationalism" make little sense. For a related discussion, see Steven Crowell's characterization of representations in phenomenological terms as "not mental items or brain states but ways of taking the world that are defined in evidential - that is to say, intrinsically normative-terms" (Normativity and Phenomenology in Husserl and Heidegger [Cambridge: Cambridge University Press, 2013], p. 105).

15. Frank Ankersmit, Meaning, Truth, and Reference in Historical Representation (Ithaca: Cornell University Press, 2012); henceforth MTR, followed by page number.

16. See Eelco Runia, "Presence," History and Theory, 45:1 (2006), pp. 1-29; henceforth $\mathrm{P}$, followed by page number.

17. Pierre Nora, Realms of Memory: Rethinking the French Past, vols. 1-3, trans. Arthur Goldhammer, ed. Lawrence D. Kritzman (New York: Columbia University Press, 1996).

18. Pierre Nora, Conflicts and Divisions, vol. 1 of Realms of Memory: Rethinking the French Past, trans. Arthur Goldhammer, ed. Lawrence D. Kritzman (New York: Columbia University Press, 1996), p. 20.

19. Timo Miettinen, "Transcendental Social Ontology," in Phenomenology and the Transcendental, ed. Sara Heinämaa, Mirja Hartimo, and Timo Miettinen (New York: Routledge, 2014), p. 153.

20. David Carr, Time, Narrative, and History (Bloomington: Indiana University Press, 1991).

21. This raises an important question: Is the narrative level of experience that Carr takes to be ontological thereby also non-conceptual? It is clear that for it to do the work Carr needs it to do, it must be non-representational and non-linguistic. But how far exactly does Carr wish to move away from his earlier conception of narrative, which he now thinks was too closely tied to the literary use of the term? This is tied to the need to extend the analysis of we-intentionality to the lived body, as noted above.

22. [Ed.-The more common contemporary spelling of this name includes an 'i', i.e., 'Raleigh'. However, it has been argued that 'Ralegh' is more historically accurate (see, for example, William Stebbing, Sir Walter Raleigh: A Biography [Hamburg: Severus, 2014], pp. 30-1). For this reason, and for the sake of consistency with Carr's preferred spelling, 'Ralegh' has been chosen for this essay.] 
23. As I have argued elsewhere, in the context of considerations of history, appeals to Ereignis and other post-Heideggerian notions of "the event," while they are right to question a too strongly active, conscious, or selfaware conception of the subject, often move too far in the opposite direction, resulting in views of history that problematically ignore the role of the concretely situated, embodied subject in the constitution of meaning, resulting in conceptions according to which the constitution of historical meaning is rendered a sort of mysterious or mystically occurring event. See my critique of Søren Olesen's version of this view in Jacob Rump, "Knowledge, Temporality, and the Movement of History," Research in Phenomenology, 44:3 (2014), pp. 441-52.

24. As developed in the work of Marc Richir, following Husserl and especially the later Merleau-Ponty's notion of “wild being” (Maurice Merleau-Ponty, The Visible and the Invisible, trans. Alphonso Lingis, ed. Claude Lefort [Evanston: Northwestern University Press, 1968]), p. 102. For an application of these notions to history in the context of a discussion of meaning closely related to the one presented here, see chap. 1 of László Tengelyi, The Wild Region in Life-History, trans. László Tengelyi and Géza Kállay (Evanston: Northwestern University Press, 2004), pp. 3-52.

25. For instance, at one point Carr discusses our "direct and lived relationship to history" through families and other communities, and then extends this analysis to physical aspects of our environments: furniture, roads, city structures, etc. (EH 53). But even here the point is quickly passed over, since "even this physical world is part of the human world of overlapping communities with which we identify ourselves" (ibid.).

26. Ludwig Wittgenstein, Philosophical Investigations, 4th ed., trans. G.E.M. Anscombe, P.M.S. Hacker, and Joachim Schulte, ed. P.M.S. Hacker and Joachim Schulte (Oxford: Blackwell Publishing, 2009), §§345, 242-3; henceforth PI, followed by section number.

27. Compare this with Steven Crowell's definition of a norm as "anything that serves as a standard of success or failure of any kind," "in short, whatever it is that measures our speech and behavior" (Normativity and Phenomenology in Husserl and Heidegger, p. 2).

28. A similar account of normativity in the phenomenological tradition has recently been advanced by Steven Crowell (Normativity and Phenomenology in Husserl and Heidegger). What I am suggesting here is closely related, but whereas Crowell's account focuses on agential aspects of normativity, largely following Heidegger, my point here-following Wittgenstein-is that some normative structures are also in a certain sense non-agential.

29. Jean-Paul Sartre, Critique of Dialectical Reason, vol. 1, trans. Alan Sheridan-Smith, ed. Jonathan Rée (New York: Verso, 2004).

30. See Sartre, Critique of Dialectical Reason, vol. 1, p. 556.

31. Paul Ricoeur, Husserl: An Analysis of his Phenomenology, trans. Edward G. Ballard and Lester E. Embree (Evanston: Northwestern University Press, 1967), p.194. 